\title{
Multiscale design of a dairy beverage model composed of Candida utilis single cell protein supplemented with oleic acid
}

\author{
H. M. Buitrago Mora, ${ }^{1}$ M. A. Piñeros, ${ }^{1}$ D. Espinosa Moreno, ${ }^{1}$ S. Restrepo Restrepo, ${ }^{2}$ J. E. C. Cardona \\ Jaramillo, ${ }^{1}$ Ó. A. Álvarez Solano, ${ }^{1}$ M. Fernandez-Niño, ${ }^{1}$ and A. F. González Barrios ${ }^{1 *}$ \\ ${ }^{1}$ Grupo de Diseño de Productos y Procesos, Department of Chemical Engineering, Universidad de los Andes, Bogotá 111711, Colombia \\ ${ }^{2}$ Vice-rectory of Research and Laboratorio de Micología y Fitopatología, Biological Sciences Department, Universidad de Los Andes, \\ Bogotá 111711, Colombia
}

\section{ABSTRACT}

One of the main challenges in the food industry is to design strategies for the successful incorporation of natural sources of bioactive compounds. Recently, yogurts and other fermented dairy beverages have been proposed as ideal carriers of such bioactive compounds such as fatty acids and antioxidants that could improve consumers' health. However, the incorporation of new ingredients causes functional and structural modifications that may affect the consumers' preferences. In this work, a dairy beverage model supplemented with oleic acid has been designed by partial substitution of milk by Candida utilis single-cell protein extract. The changes in the structural properties of this new beverage were evaluated by following the fermentation process, $\mathrm{pH}$, aggregate size, microstructure, and changes in rheological properties. Furthermore, molecular dynamics simulations were carried out to analyze the interaction between its main components. Our data revealed that samples with a percentage of milk substitution of $30 \%$ showed a higher viscosity as compared with the other percentages and less viscosity than the control (no substitution). These samples were then selected for fortification by incorporating oleic acid microcapsules. A concentration of $1.5 \mathrm{~g} / 100 \mathrm{~g}$ was shown to be the optimal quantity of microcapsules for oleic acid supplementation. Molecular dynamic simulations revealed glutathione as an important component of the microgel structure. The present study forms the basis for novel studies where Candida utilis single-cell protein and microencapsulated essential oils could be used to design innovative bioproducts.

Key words: fermented dairy beverage, single cell protein, Candida utilis, microencapsulation, multiscale design

Received April 1, 2019.

Accepted July 10, 2019.

*Corresponding author: andgonza@uniandes.edu.co

\section{INTRODUCTION}

Fermented dairy beverages (FDB) are among the most consumed milk products in the world (Sakin-Yilmazer et al., 2014; Pandalaneni et al., 2018; Cordeiro et al., 2019). In addition to their high nutritional value, FDB have been associated with many health benefits because of their microbial composition and functional metabolites (Macedo and Vélez-Ruíz, 2015; Pelaes et al., 2015; Vardjan et al., 2018; Aguilar-Raymundo and Vélez-Ruiz, 2019). Today, FDB have become an excellent matrix to deliver bioactive compounds that might enhance people's health and reduce the risk of some diseases (Macedo and Vélez-Ruíz, 2015). In this regard, a large number of fermented dairy beverages have been designed with the addition of bioactive compounds to deliver extra health benefits over their basic nutritional value (Chouchouli et al., 2013; Pelaes et al., 2015; Barkallah et al., 2017; Öztürk et al., 2018; Aguilar-Raymundo and Vélez-Ruiz, 2019). Many of these additives such as n-3, Nigella sativa seed oil, echium oil, marine fish oil, astaxanthin from Phaffia rhodozyma, and $\beta$-carotene have been microencapsulated prior to addition to delay their degradation (Estrada et al., 2011; Toniazzo et al., 2014; Abedi et al., 2016; Comunian et al., 2017; Feng et al., 2018). One of the most interesting functional components that could be incorporated into an FDB is oleic acid (OA). This MUFA has been associated with several health benefits, such as a reduction in low-density lipoprotein cholesterol levels and the total cholesterol/high-density lipoprotein-C ratio (FAO and FINUT, 2012). In addition, supplementation with 0.28 $\mathrm{mg}$ of OA in Swiss-Webster mice diet has been shown to prevent organ dysfunction and mortality in experimental sepsis (Gonçalves-de-Albuquerque et al., 2016). Interestingly, a $4 \%$ OA supplementation in the total calories consumed by Wistar mice showed an antioxidant effect, generating a neurodegenerative oxidation effect in a Huntington's disease experimental model (Alconchel-Gago et al., 2014). However, given that OA is susceptible to oxidation by oxygen or light, it might 
be necessary to use innovative technics to improve its thermostability, as well as maintain its functional and biological activity (López Hernández, 2010; Bakry et al., 2016). Consequently, one of the main challenges in the beverage industry is to develop strategies for the successful incorporation of natural sources of bioactive compounds in FDB such as fatty acids and single-cell protein $(\mathbf{S C P})$.

The yeast Candida utilis is an excellent platform for the production of SCP for animal and human feeding (Buerth et al., 2016). This yeast has an important nutritional value, possessing a high protein content (55\%) and an interesting AA profile, which includes lysine $(4.5 \%)$, threonine $(3.0 \%)$, histidine $(2.0 \%)$, and arginine $(4.9 \%)$, as well as B-complex vitamins (Lucca et al., 1995). Moreover, C. utilis has endogenous bioactive compounds such as glutathione, glucomannan, biotin, and L-phenylacetylcabinol (Buerth et al., 2011a; Tomita et al., 2012), thus becoming an interesting natural source of both protein and bioactive compounds. Nevertheless, no studies have been reported in which $C$. utilis or its extract have been incorporated in FDB.

The incorporation of new ingredients in FDB causes functional and structural modifications, thus affecting consumers' preferences (Pelaes et al., 2015; Vardjan et al., 2018; Aguilar-Raymundo and Vélez-Ruiz, 2019). These changes in macroscopic properties are related to the microstructure that is formed by suspended solids, the aggregate formation profile in gel transformation, and the exopolysaccharides from bacteria (Rodríguez et al., 2015; Vardjan et al., 2018). The aggregate formation and microstructure depend on temperature, $\mathrm{pH}$ reduction, and other aspects not yet elucidated (Lee and Lucey, 2010). At the molecular level, milk caseins interact with one another and with the new molecules incorporated, where $\kappa$-casein plays an important role in acid gelation (Dalgleish and Corredig, 2012). The aim of this work was to study the effect of partial substitution of milk by Candida utilis SCP extract and the subsequent supplementation with microencapsulated OA using a multiscale approach (Charpentier, 2002; Pradilla et al., 2015).

\section{MATERIALS AND METHODS}

\section{Strain and Growth Conditions}

Candida utilis ATCC 9950 (Kwik-Stik, Microbiologics Inc., St. Cloud, MN) was routinely cultivated on solid potato dextrose agar medium for $48 \mathrm{~h}$ at $30^{\circ} \mathrm{C}$, following the streak-plating method. Cells from a single colony were then used to inoculate $500 \mathrm{~mL}$ of liquid yeast extract-peptone-dextrose (YPD) medium, containing $10 \mathrm{~g} / \mathrm{L}$ of yeast extract, $20 \mathrm{~g} / \mathrm{L}$ of peptone, and $20 \mathrm{~g} / \mathrm{L}$ of dextrose. Cultures were subsequently incubated in an orbital shaker at $250 \mathrm{rpm}$ and $30^{\circ} \mathrm{C}$ for $16 \mathrm{~h}$. Optical densities (OD) were determined at $473 \mathrm{~nm}$ using a Genesys 10s UV-Vis spectrophotometer (Thermo Fisher Scientific, Waltham, MA) until an OD of 2.13 was reached. This culture was then used as inoculum for batch fermentations.

Batch fermentations were carried out using a BioFlo/ CelliGen 115 bioreactor (New Brunswick, Germany), containing $4.5 \mathrm{~L}$ of YPD medium. Fermentations were carried out at $30^{\circ} \mathrm{C}$, with an aeration rate of $1 \mathrm{~L} / \mathrm{min}$ and continuous agitation for $8 \mathrm{~h}$ at $300 \mathrm{rpm}$, until an $\mathrm{OD}=1.82$ was reached. This fermented broth was then transferred into plastic bottles, centrifuged at $1,400 \times$ $g$ for $30 \mathrm{~min}$ at $16^{\circ} \mathrm{C}$, recovered in 50 -mL plastic tubes and finally centrifuged at $1,400 \times g$ for 15 min at $16^{\circ} \mathrm{C}$. The obtained pellet was washed 3 times with ultrapure water (Direct-Q 3UV-R, Merck-Millipore, Burlington, MA), thus obtaining the SCP biomass.

\section{Biomass Characterization and Protein Extraction}

Moisture (AOAC 934.01; AOAC International, 1995) and total nitrogen Kjeldahl (SSSA series 5) (Bremner, 1996) were determined for SCP biomass. Protein content in SCP biomass was determined by multiplying the total nitrogen value by a nitrogen conversion factor of 6.25, as described by Øverland et al. (2013) and expressed on a dry basis (g/100 g). To use SCP biomass as a protein source in beverage fermentations, an initial lysis step by thermic treatment $\left(-20\right.$ to $\left.50^{\circ} \mathrm{C}\right)$ was required, followed by separation of the cellular membrane through centrifugation at $1,400 \times g$ for $10 \mathrm{~min}$. The obtained single-cell protein extract (SCPE) was diluted with deionized water to obtain a concentration of 3.2 $\mathrm{g} / 100 \mathrm{~mL}$, and the total protein content was then estimated using a NanoDrop ND-1000 spectrophotometer (Thermo Fisher Scientific).

\section{Beverage Fermentation Procedure}

Dairy single-cell protein extract beverages (DASCPEB) were prepared using skimmed and lactose-free UHT milk (Alpina, Colombia; i.e., $3.2 \mathrm{~g} / 100 \mathrm{~mL}$ of protein and $8.2 \mathrm{~g} / 100 \mathrm{~mL}$ of $\mathrm{DM}$ ) and the effects of milk substitution with SCPE in beverage fermentations were subsequently determined. A dairy beverage without substitution was used as control ( $0 \%$ substitution) and experiments were carried out by mixing SCPE with milk in fermentation flasks in the following proportions: $10,20,30,40,50$, and $60 \mathrm{~mL} / 100 \mathrm{~mL}$. Then, DASCPEB non-fatty solids were standardized to 8.2 $\mathrm{g} / \mathrm{L}$ using sugar (Manuelita, Cali, Valle del Cauca, Colombia) and subsequently homogenized. After that, the 
different mixes prepared and the control samples were inoculated with $0.1 \mathrm{~g} / 100 \mathrm{~mL}$ of commercial lyophilized starter culture containing Streptococcus thermophilus, Lactobacillus delbrueckii (Lactobacillus bulgaricus), and Bifidobacterium (Centro Agrolechero, Bogotá, Colombia). Finally, samples were fermented by incubation at $42^{\circ} \mathrm{C}$ for $6 \mathrm{~h}$ and stopped by cooling. At least 2 biological replicates of each experiment were carried out.

\section{Oil in Water Emulsions}

Before OA microencapsulation, 5 emulsions were prepared according to Di Battista et al. (2015) with some modifications. Initially, Arabic gum (15 g/100 g) and maltodextrin $(5 \mathrm{~g} / 100 \mathrm{~g})$ were dissolved in water and heated at $50^{\circ} \mathrm{C}$ for complete dissolution (mix-1). Then, OA (5 g/100 g) and Tween 20 were added in different ratios (i.e., 1, 2, 3, 4, and $5 \mathrm{~g} / 100 \mathrm{~g}$ ) until dissolution was observed (mix-2). Mix-1 was cooled at $25^{\circ} \mathrm{C}$ and homogenized at 3,000 rpm using a Dissolver LC75 DISPERMAT (VMA, Reichshof, Germany) and mix-2 was added drop by drop to it, allowing emulsion formation. The obtained mix (mix-3) was further homogenized for $20 \mathrm{~min}$. Finally, each emulsion was homogenized for 9 min at 24,900 rpm, using a Miccra D-15 homogenizer (Miccra, Heitersheim, Germany).

Emulsion stability was determined by scan transmission and backscattering using a Turbiscan LAB Stability Analyzer (Formulaction SA, Toulouse, France). A total of $15 \mathrm{~mL}$ of each emulsion was used for this analysis, for a time period of $45 \mathrm{~min}$. Turbiscan stability index was determined. Drop formation was evaluated using a BA301 optical microscope (Motic, Hong Kong), while its distribution was determined by dynamic light scattering (DLS) using a Mastersizer 3000 equipment (Malvern Instruments, Malvern, UK). The Brouckere mean diameter $\mathrm{D}[4,3]$ was determined for samples diluted in deionized water, displaying $10.5 \%$ of obscurity. Finally, the most stable emulsion (i.e., $4 \%$ surfactant emulsion) was selected and total suspended solids (total feed solids) were measured before drying using a 30033 refractometer (Sper Scientific, Scottsdale, AZ).

\section{Oleic Acid Microencapsulation-Spray-Drying}

Initially, the obtained emulsion was dried using a Mini Spray Dryer (B-290, Büchi Labortechnik AG, Flawil, Switzerland) provided with a $0.7-\mathrm{mm}$ diameter nozzle. Operating conditions included setting the following conditions: drying air inlet temperature at $160^{\circ} \mathrm{C}$, atomization air in-flow rate at $601 \mathrm{~L}_{\text {air }} / \mathrm{h}$, feed volumetric flow rate at $4 \mathrm{~mL} / \mathrm{min}$, and drying air volumetric flow rate at $35 \mathrm{~m}^{3} / \mathrm{h}$. Process yield (PY) was assessed according to Di Battista et al. (2015) using the following equation:

$$
\mathrm{PY}=[(\text { powder weight obtained }) /(\mathrm{TS} \text { fed })] \times 100 \% \text {. }
$$

Microencapsulation efficiency (MEE) was calculated using equation 2, as previously reported by (JiménezMartín et al., 2014). Briefly, the total OA amount (TOA) was determined using $2 \mathrm{~g}$ of microcapsules, where the total oily matter was recovered using a Soxhlet extraction system with n-hexane during $4 \mathrm{~h}$ by rotary evaporation, and then it was weighted. For free OA amount (OAF), $2 \mathrm{~g}$ of microcapsules was diluted in $20 \mathrm{~mL}$ of ethyl ether, heated to $50^{\circ} \mathrm{C}$, and filtered initially with an 11-mm filter, and subsequently, using a $0.22-\mu \mathrm{m}$ filter. Then, this solvent was evaporated using a rotary evaporator and the remaining oil matter was weighted afterward.

$$
\mathrm{MEE}=(\mathrm{TOA}-\mathrm{OAF} / \mathrm{TOA}) \times 100 \% .
$$

Microcapsule morphology was then evaluated using a Phenom Pro X Scanning Electron Microscope (Phenom-World, Eindhoven, the Netherlands). Microcapsules were initially fixed on a stub cover with carbon tape and sputtered with gold. Images were visualized at $10 \mathrm{kV}$ and recorded. The microcapsule size distribution was measured by DLS using a Mastersizer 3000 equipment (Malvern Instruments), dissolving the powder in $500 \mathrm{~mL}$ of deionized water until $10.5 \%$ obscurity was obtained, and then the Brouckere mean diameter $\mathrm{D}[4,3]$ was determined.

\section{Microcapsule Supplementation Containing Oleic Acid}

The DASCPEB in a ratio of $30 \mathrm{~mL} / 100 \mathrm{~mL}$ was selected as the upper limit substitute for microcapsule supplementation and was subsequently used to assess the supplementation effect on the beverage properties. Three independent DASCPEB (all of them in a ratio of $30 \mathrm{~mL} / 100 \mathrm{~mL}$ ) were fermented, stirred, and further supplemented with microcapsules at concentrations of $\mathrm{S}-\mathrm{A}=1.5, \mathrm{~S}-\mathrm{B}=3$, and $\mathrm{S}-\mathrm{C}=4.5 \mathrm{~g} / 100 \mathrm{~g}$, respectively. Supplementation was initially carried out in $10 \%$ of its original volume to avoid changes on viscosity. Then, the volume was completed with the remaining DASCPEB volume. The DASCPEB in a ratio of $30 \mathrm{~mL} / 100 \mathrm{~mL}$ without supplementation was used as the experimental control. At least 2 biological replicates of each experiment were carried out. Samples were stored at $4^{\circ} \mathrm{C}$ to further evaluate their physicochemical properties. 


\section{Physicochemical Determinations}

$\mathrm{pH}$ was measured each hour in the substitution experiment and at 1, 8, 15, and $21 \mathrm{~d}$ for the supplementation experiment, using a Seven-Compact $\mathrm{pH}$-meter (Mettler Toledo, Columbus, $\mathrm{OH}$ ). Additionally, the physical properties cited below were measured at the same time intervals as $\mathrm{pH}$.

Rheological Behavior. Rheological properties of beverages were characterized using a Discovery HR-1 rheometer (TA Instruments, New Castle, DE), equipped with a concentric geometry cylinder (Deutsches Institut für Normung, $15 \mathrm{~mm}$ radius and $42 \mathrm{~mm}$ height) and Peltier temperature control that kept the samples at $20^{\circ} \mathrm{C}$. An aliquot of $20 \mathrm{~mL}$ of each sample was loaded in the cylinder, pre-sheared for $60 \mathrm{~s}$ at $1 \mathrm{~s}^{-1}$, and followed by a back and forth sweep probe, from 1 to $500 \mathrm{~s}^{-1}$ shear rates.

Average Aggregate Size. The average aggregate size as a function of $\mathrm{pH}$ and storage time was determined according to Rodriguez et al. (2013) by DLS using a Mastersizer 3000 equipment (Malvern Instruments), maintaining 10.5 to $11.0 \%$ of obscurity. Measurements were recorded 5 times for each sample and the Sauter mean diameter $(\mathrm{D}[3,2])$ average was determined.

Microstructure. The obtained beverage gel microstructure was observed using a Phenom Pro X Scanning Electron Microscope (Phenom-World). Initially, an aliquot of $5 \mu \mathrm{L}$ of each sample was placed on a stub cover with carbon tape, then dried in a convection oven at $25^{\circ} \mathrm{C}$, and subsequently sputtered with gold covering. Finally, samples were observed at $10 \mathrm{kV}$ and micrographs were obtained. For the substitution assay, micrographs were taken at the start and the end of the fermentation, whereas for the supplementation assay, they were taken on $\mathrm{d} 1$ and after $21 \mathrm{~d}$.

\section{Molecular Dynamics Simulations}

In silico assays were carried out using molecular dynamics (MD) to study the glutathione interactions with C. utilis extracts, microcapsule components, and milk proteins. First, we selected the $\kappa$-casein as the protein expected to interact with other components in dairy beverage formation and glutathione as the bioactive component from the extract. The $\kappa$-casein AA sequence (accession number: AAQ87923.1) was downloaded from the National Center for Biotechnology Information web page. The tertiary structure of kappa casein was predicted by homology using the ITASSER (Iterative Threading ASSEmbly Refinement) protocol (Zhang, 2008; Roy et al., 2010; Yang et al., 2015) with a C-score of -4.13 . Then, maltodextrin,
OA, and glutathione 3-dimensional structures were downloaded from PubChem (Kim et al., 2016). Arabic gum 3-dimensional structure was drawn according to Ikram and Ahnmed (2016) in Avogadro 1.2 (an opensource molecular builder and visualization tool), and the energy minimization structure was carried using universal force field in 5,000 cycles of steepest descent. Topologies for small molecules were then generated using SwissParam (Zoete et al., 2011) and the protein topology was generated with Intermol (Shirts et al., 2017). Next, the fourth cubic simulation box was created with $11 \mathrm{~nm}^{3}$ and periodic boundaries for (a) free $\kappa$-casein, (b) solvated $\kappa$-casein, (c) solvated $\kappa$-casein and glutathione, and (d) $\kappa$-casein solvated with glutathione, Arabic gum, maltodextrin, and OA.

Molecular dynamics simulations were run using LAMMPS version 11-Aug-17 (http://lammps.sandia .gov; Plimpton, 1995) into an Ubuntu virtual machine using a hybrid inter-harmonical potential (harmonic and CHARM) and applying the following script code steps: (1) one minimization on steepest descent followed by one on a conjugate gradient, and (2) an equilibration during $0.35 \mathrm{~ns}$ in an NVE system. Finally, the simulation by 1 ns with a Berendsen thermostat to $298 \mathrm{~K}$ in an NPT (number of particles, pressure, and temperature) system was done. The trajectory and the results were visualized in Ovito (http://ovito.org; Stukowski, 2010).

\section{RESULTS AND DISCUSSION}

\section{SCP Biomass and SCP Extracts Were Obtained from Batch Fermentations of $C$. utilis}

Batch fermentations of $C$. utilis were initially performed to obtain SCP biomass. Biomass of $3.36 \mathrm{~g} / \mathrm{L}$ on a dry basis was obtained, which agrees with that reported in the literature where $C$. utilis net biomasses ranged from 2.9 to $9.80 \mathrm{~g} / \mathrm{L}$ (Tobajas et al., 2003; García et al., 2014; Prakash and Mohamed, 2017). These values have been also shown to be affected by medium composition and operating conditions (Tobajas et al., 2003; García et al., 2014; Prakash and Mohamed, 2017). The total protein and moisture content in SCP biomass were then determined following the standard protocols described in the Materials and Methods section. The total protein content of $40.02 \mathrm{~g} / 100 \mathrm{~g}$ on a dry basis and moisture content of $71.99 \mathrm{~g} / 100 \mathrm{~g}$ were obtained.

The protein value reported here was lower than that frequently reported in the literature (i.e., ranging from 43.24 to $49.95 \mathrm{~g} / 100 \mathrm{~g}$ ), which can be explained by the fact that a different carbon source was used and experiments were conducted without supplementation 


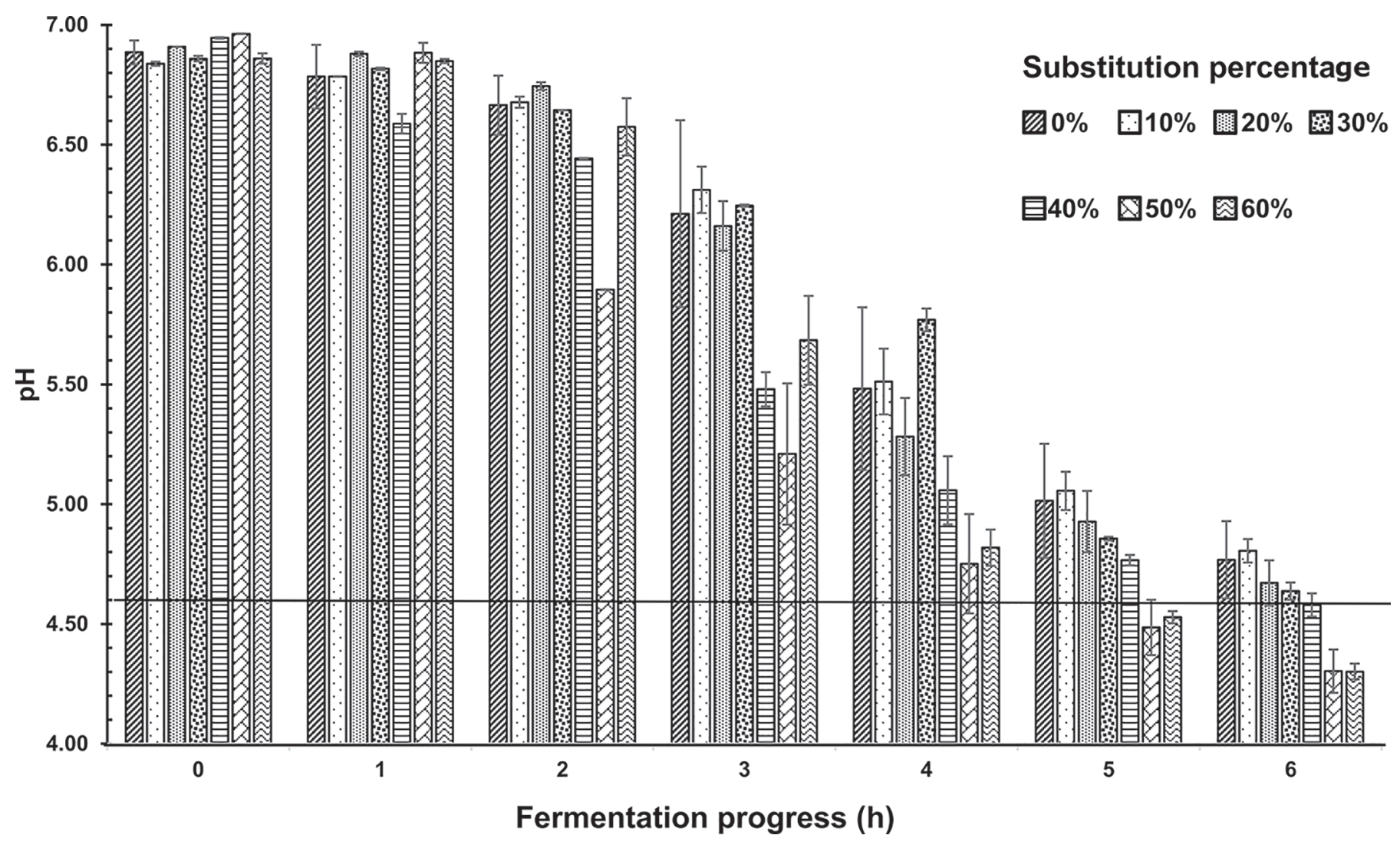

Figure 1. pH profiles for dairy single-cell protein extract (SCPE) beverages during fermentation. Experiments were carried out by mixing SCPE with milk in fermentation flasks in the following proportions: 0 (control), 10, 20,30, 40, 50, and $60 \mathrm{~mL} / 100 \mathrm{~mL}$ (shown here as substitution percentage). Graphics show each $\mathrm{pH}$ profile per sample, taken each hour during $6 \mathrm{~h}$ of fermentation. Error bars represent SD. The horizontal line indicates the isoelectric point of casein.

(Carrillo et al., 2010; Buerth et al., 2011b; Rodríguez et al., 2011). Finally, an extract of $C$. utilis SCP was obtained by thermic treatment and separation of the cellular membrane. The total protein content in this extract was determined to show a value of $3.26 \pm 0.08$ $\mathrm{g} / 100 \mathrm{~g}$.

\section{SCPE Substitution Seems to Differentially Affect the $\mathrm{pH}$ During DASCPEB Fermentations}

The $\mathrm{pH}$ of DASCPEB decreased through fermentations in response to lactic acid production during bacteria growth. Our results suggest that the percentage of SCPE substitution seems to differentially affect the $\mathrm{pH}$ through the fermentation (Figure 1). This effect can be related to the fiber present in the extract (Puvanenthiran et al., 2014; Pelaes et al., 2015). Lower percentages of SCPE substitution (i.e., 10, 20, and $30 \mathrm{~mL} / 100$ $\mathrm{mL}$ ) displayed a behavior comparable to the control (i.e., 0\% substitution). In contrast, higher percentages of substitution $(40,50$, and $60 \mathrm{~mL} / 100 \mathrm{~mL})$ showed a steeper decrease, especially after $4 \mathrm{~h}$ of fermentation
(Figure 1). These samples were shown to exceed the isoelectric point of caseins $(\mathrm{pH}=4.6)$ after $6 \mathrm{~h}$ of fermentation. Thus, samples were divided into 2 groups according to their substitution percentage: low $(10,20$, and $30 \mathrm{~mL} / 100 \mathrm{~mL}$ ) and high substitution (40, 50, and $60 \mathrm{~mL} / 100 \mathrm{~mL}$ ).

\section{DASCPEB Fluid Behavior Was Affected According to the Amount of Milk Substituted by SCPE}

The fluid behavior and apparent viscosity of DASCPEB were measured using a rheometer. All DASCPEB showed an apparent decrease in viscosity, while the shear rate increased, which resembles a typical pseudoplastic behavior (Figure 2) and follows the power law, $\sigma$ $=\mathrm{k}(\gamma)^{\mathrm{n}}$, where $\sigma$ is the shear stress, $\mathrm{k}$ is the consistency index (apparent viscosity), $\gamma$ is the shear rate, and $n$ is the fluid behavior.

An increase in apparent viscosity was shown to vary in response to the fermentation time and SCPE concentration. The apparent viscosity of DASCPEB was shown to remain constant during the first 1 to $3 \mathrm{~h}$ 
of fermentation (Supplemental Figure S1, https://doi .org/10.3168/jds.2019-16729), continuously increase after $4 \mathrm{~h}$, and finally decrease after $6 \mathrm{~h}$ (at the end of the fermentation; Figure 3). It is important to mention that an increase in viscosity was directly observed during the first hours of fermentation for the sample with a $50 \%$ substitution, which could be associated with the rapid $\mathrm{pH}$ drop analyzed previously for this sample, whereas the other samples remained constant during this time.

The sample that showed the highest increase in apparent viscosity after $6 \mathrm{~h}$ (i.e., $1.230 \pm 0.022 \mathrm{~Pa} \cdot \mathrm{s}$ ) was that with a $30 \%$ of substitution, which agrees with the reported by Castro et al. (2013), who also observed a high apparent viscosity (i.e., $0.821 \pm 0.030 \mathrm{~Pa} \cdot \mathrm{s}$ ) in samples where milk was substituted by whey. Nevertheless, it is important to mention that after $6 \mathrm{~h}$ all samples showed a lower apparent viscosity as compared with the control (Figure 3), which is concomitant with the fact that $\mathrm{pH}$ decreased after $4 \mathrm{~h}$.

Viscosity is one of the most important consumer characteristics in dairy products and is affected by the solids volume suspended in a liquid, the starter culture, and the fortification, among other things (Lee and Lucey, 2010; Rodríguez et al., 2015). When the beverage was fortified with natural sources as Spirulina platensis powder or Pleurotus ostreatus extract, the beverage stiffness decreased and the viscosity was affected in a positive or negative way (Pelaes et al., 2015; Barkallah et al., 2017). To carry out a rational beverage design and understand what happens when a natural bioactive source is incorporated, it is also important to understand the casein aggregation profile, the microstructure, and the relevant molecular interactions involved.

\section{A Low Amount of Milk Substituted by SCPE Exhibited a Similar Aggregation Profile to a Dairy Beverage}

The DLS technique was reported to obtain the aggregation profiles (size increase) as a function of $\mathrm{pH}$ and time in beverage fermentation (Lee and Lucey, 2010; Rodríguez et al., 2015). The control sample showed an aggregation profile in accordance with previous studies (Figure 4A). Briefly, for $\mathrm{pH}$ values between 6.7 and 6 , no increase was shown. After that, the aggregation profile exhibited 2 inflection points at $\mathrm{pH} 6.0$ and 5.0, the first corresponding to a net charge decrease, an increase in the steric stability, and a rise in the colloidal calcium

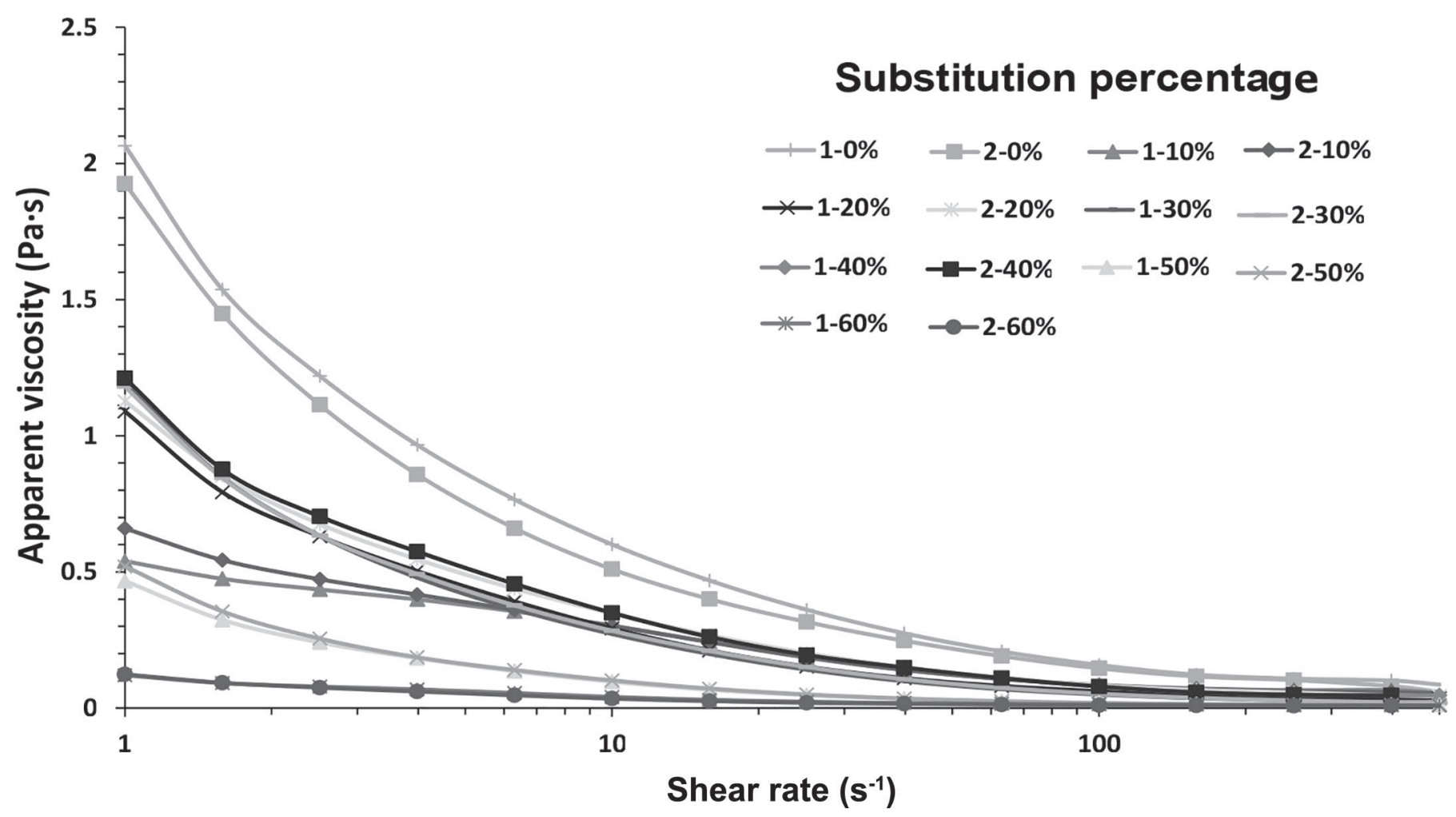

Figure 2. Fluid behavior for dairy single-cell protein extract (SCPE) beverages in a shear rate from 0 to $500 \mathrm{~s}^{-1}$. Trends show the pseudoplastic behavior for each sample, and as it increases, this behavior decreases. Experiments were carried out by mixing SCPE with milk in fermentation flasks in the following proportions: 0 (control), 10, 20,30,40,50, and $60 \mathrm{~mL} / 100 \mathrm{~mL}$ (shown here as substitution percentage). 


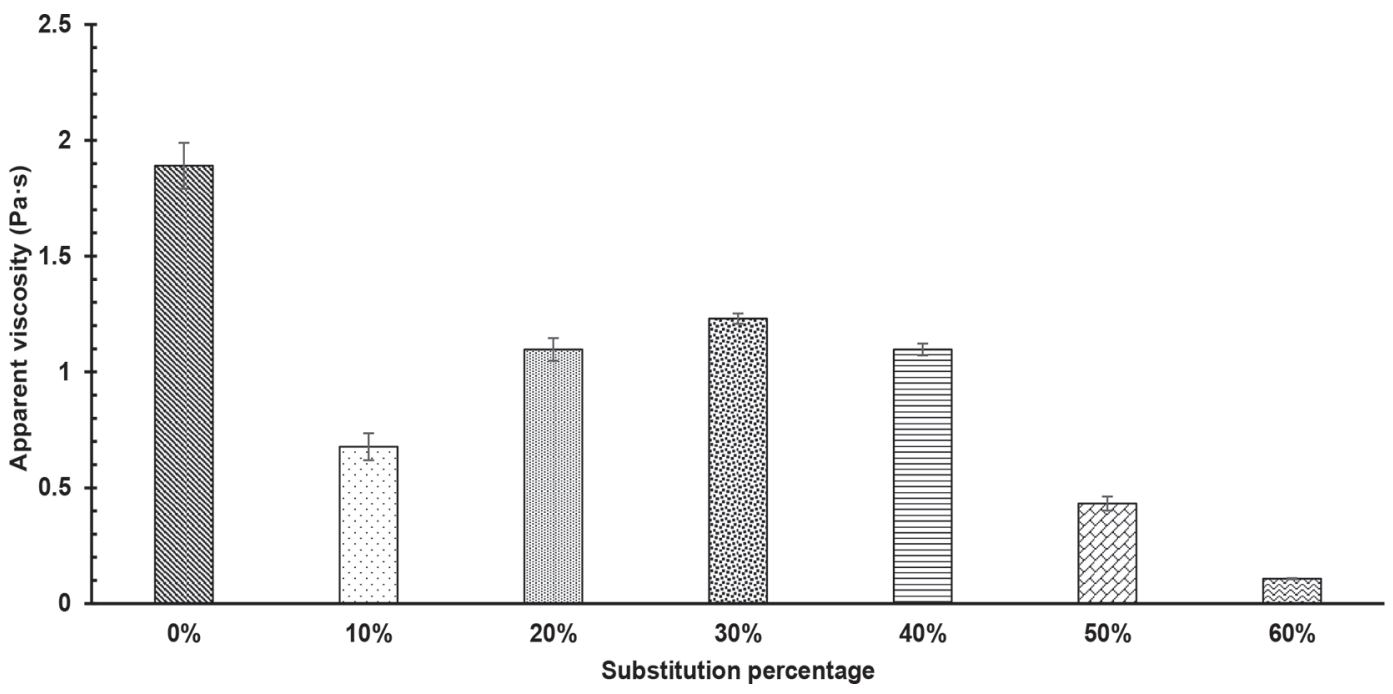

Figure 3. Apparent viscosity (k value) for each treatment. The graphic shows the apparent viscosity for each treatment after $6 \mathrm{~h}$ of fermentation. Experiments were carried out by mixing single-cell protein extract with milk in fermentation flasks in the following proportions: 0 (control), 10, 20, 30, 40, 50, and $60 \mathrm{~mL} / 100 \mathrm{~mL}$ (shown here as substitution percentage). Error bars represent SD.

phosphate dissolution rate, and consequently, an increase in the aggregate size. Second, at a $\mathrm{pH}$ lower than 5.0 all the colloidal calcium phosphate is lost, favoring hydrophobic and short-range interactions to cause the sol-gel formation (Lee and Lucey, 2010; Dalgleish and Corredig, 2012). Therefore, the DLS measurements can be used to identify trends for DASCPEB aggregation profiles.

All of the treatments showed a particle size increase after 3 fermentation hours, an early increase $(2 \mathrm{~h})$ for the sample at $50 \%$, and any change exhibited at $60 \%$ (Supplemental Figure S2, https://doi.org/10.3168/ jds.2019-16729; Figure 4B and C), which explain the behavior described above regarding the viscosity. The $10 \%$ DASCPEB presented a delay in the particle size increase ( $\mathrm{pH}$ 5.5; Figure 4B); meanwhile, samples at 20 and $30 \%$ present a slight acceleration effect (in the 3rd hour) and increased particle sizes at $\mathrm{pH} 6.15$ and 6.64, respectively. Besides, the sample at $30 \%$ for $5 \mathrm{~h}$ achieved a particle size similar to the control sample $(12.6 \mu \mathrm{m})$ at $7 \mathrm{~h}$ later (data not shown in Figure $4 \mathrm{~A})$. A high substitution percent exhibited a different particular trend (Figure 4C): at a pH of 5.5, the sample at $40 \%$ had the same increase in particle size as the sample at $10 \%$; the only difference is that the first one obtained this increased particle size $1 \mathrm{~h}$ before. On the other hand, samples at 50 and $60 \%$ showed a disorganized aggregation. The DASCPEB kinetics of protein aggregation play an important role and were directly associated with the viscosity obtained. As it is well known for dairy beverage formation, $\mathrm{pH}$ and temperature have a specific effect on forming protein-protein bonds, and in consequence, cause a rearrangement of the protein clusters and microstructure formation. This microstructure influences viscosity (Lee and Lucey, 2010; Rodríguez et al., 2015).

\section{A Low Amount of Milk Substituted by SCPE Displayed a Similar Microstructure as Dairy Beverage}

The casein 3-dimensional network is shown in globular forms alternated with void spaces due to dried whey (Sah et al., 2016). The DASCPEB microstructure variation was observed by scanning electron microscopy (Figure 5). These microstructure variations showed a characteristic net compared with the control sample, whereas the SCPE fraction that increases the branched network was more separated. A high amount of substituted SCPE $(40,50$, and $60 \%)$ results in a network with bigger void zones (Figure $5 \mathrm{E}, \mathrm{F}$, and $\mathrm{G}$ ), and in contrast, a lesser amount of substituted $\mathrm{SCPE}(10,20$, and $30 \%$ ) did not show a considerable change (Figure $5 \mathrm{~B}, \mathrm{C}$, and D). This gel-network arrangement pointed out a particular protein aggregation to the $\mathrm{pH}$ decrease and microstructure formation. By having a net with more separated voids, there is a loss or escape of the serum contained inside, and therefore, a less firm gel (Lee and Lucey, 2004). These may have a relationship with the apparent viscosity obtained and profile aggregation. The results are in agreement with those of Sah et al. (2016), which describe a remarkable difference in beverage microstructure when it is supplemented with prebiotics, rather than when it is not supplemented. 

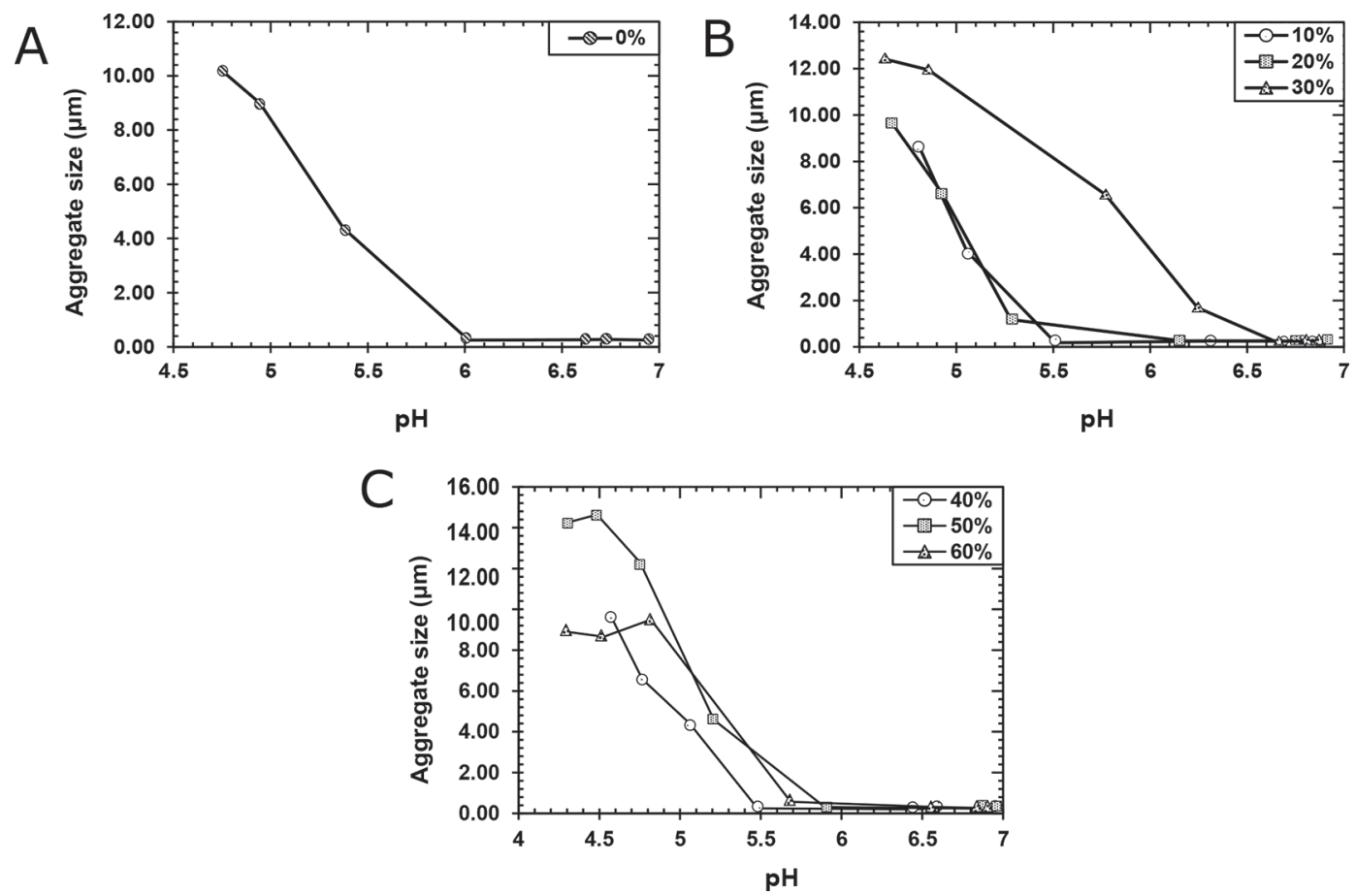

Figure 4. Aggregate size depending on $\mathrm{pH}$ for each treatment. (A) Control (0\%), (B) low substitution dairy single-cell protein extract (SCPE) beverages, and (C) high substitution dairy SCPE beverages. Experiments were carried out by mixing SCPE with milk in fermentation flasks in the following proportions: $0,10,20,30,40,50$, and $60 \mathrm{~mL} / 100 \mathrm{~mL}$ (shown here as percentages). Graphics show the aggregation profile and the starting point to increase the size of each sample.

\section{Microcapsule Formation}

The emulsions with 1 and $2 \mathrm{~g} / 100 \mathrm{~g}$ of surfactant did not show stability in an evaluated period and exhibited a flocculation phenomenon (Supplemental Figure S3, https://doi.org/10.3168/jds.2019-16729). On the other hand, the 3,4 , and $5 \mathrm{~g} / 100 \mathrm{~g}$ of surfactant emulsions showed stability during the $45 \mathrm{~min}$ that they were assessed. This stability was related to drop formation (Supplemental Figure S4, https://doi.org/10.3168/jds .2019-16729) given by the surfactant capacity to reduce the interfacial tension and encapsulate the OA. The drop distribution has a Gaussian distribution, and $\mathrm{D}[4,3]$ was $1.24,1.58$, and $1.71 \mu \mathrm{m}$ for stable emulsions, respectively. These values increased according to surfactant concentration.

The $4 \mathrm{~g} / 100 \mathrm{~g}$ surfactant emulsion was selected for the microencapsulation process and was used for the following experiments. The emulsion was dried, and the microcapsules obtained in scanning electron microscopy exhibited some typical deformations, appearing as softly dented and wrinkled spheres (Figure 7B). This morphology is characteristic of polymeric systems dried by spray drying (Di Battista et al., 2015; Abedi et al., 2016). Particle microencapsulation size and efficiency are the most important quality parameters in microcapsules (Di Battista et al., 2015). Microcapsules presented a polydisperse distribution (Figure 7A) and the particle size $(\mathrm{D}[4,3])$ was $5.18 \mu \mathrm{m}$ (Table 1$)$. In several previous studies, the microcapsule particle sizes for beverage supplementation were between 1 to $42 \mu \mathrm{m}$ for oily bioactive compounds and from 2 to $74 \mu \mathrm{m}$ for others bioactive compounds (Estrada et al., 2011; Toniazzo et al., 2014; Abedi et al., 2016; Comunian et al., 2017; Tan et al., 2018). Therefore, the microcapsules obtained could be used for DASCPEB supplementation. However, MEE was $50.79 \%$ and it was low in comparison with what was reported, which was from 75.50 to $90.10 \%$ by Estrada et al. (2011) and Abedi et al. (2016) for oily compounds with the same microencapsulation technique. The MEE in the present study might be further enhanced by improving the solids concentration or using other wall materials.

\section{Effect of DASCPEB Microcapsule Fortification}

$p H$ of DASCPEB in Storage. Only $30 \%$ of DASCPEB was used in the fortification experiment. Supplemented DASCPEB and the control sample showed a $\mathrm{pH}$ decrease in the first storage day and a continuous trend for $21 \mathrm{~d}$ (Table 2). This might be caused mainly by lactic acid produced from bacteria growth, but with a lower metabolism rate, which is called post-acidification (Comunian et al., 2017). Supplemented DASCPEB 

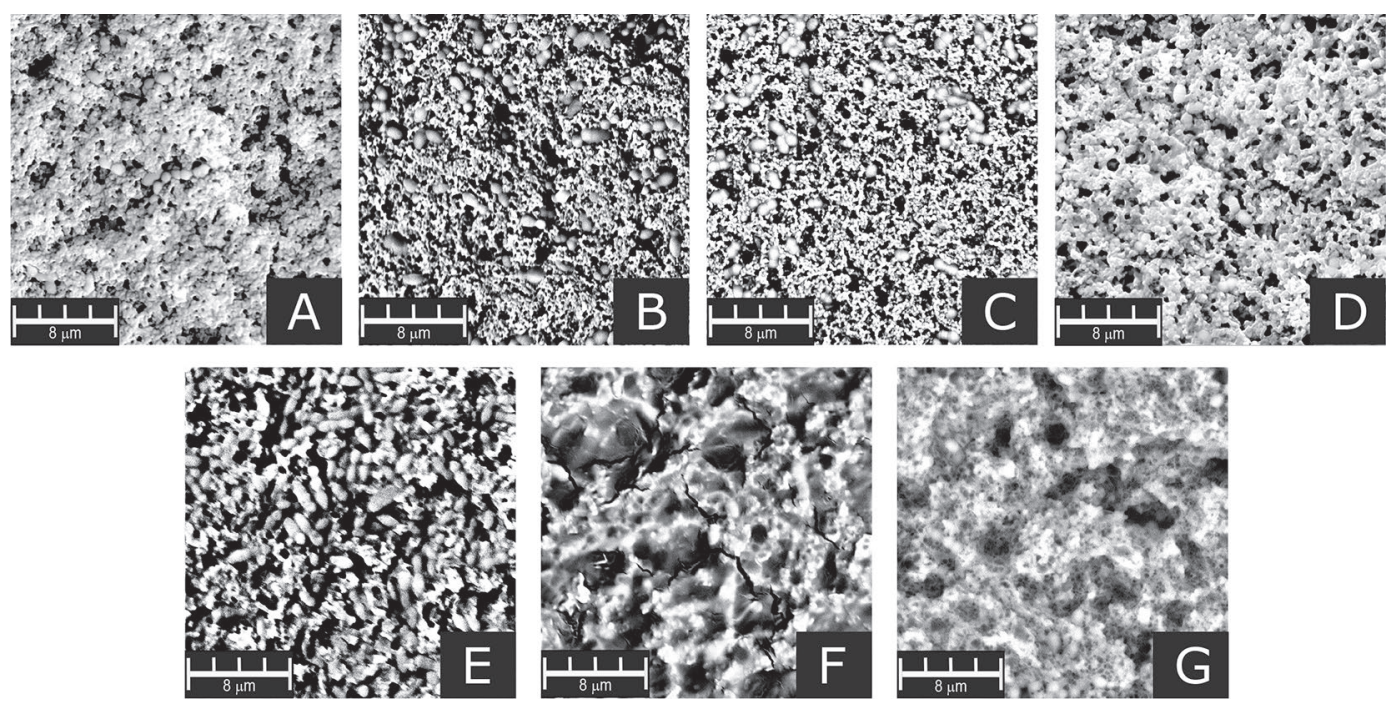

Figure 5. Micrographics for each sample at 5,000× in the $6 \mathrm{~h}$ of fermentation. (A) Control (0\%), (B) 10\%, (C) 20\%, (D) 30\%, (E) 40\%, (F) $50 \%$, and (G) 60\%. Experiments were carried out by mixing single-cell protein extract (SCPE) with milk in fermentation flasks in the following proportions: $0,10,20,30,40,50$, and $60 \mathrm{~mL} / 100 \mathrm{~mL}$ (shown here as percentages). Micrographics exhibit how as SCPE increases, the microstructure voids increase as well.

S-A had no significant effect on DASCPEB pH regarding the control sample. This result is consistent with those reported by Estrada et al. (2011) and Abedi et al. (2016), which conclude that there was no significant $\mathrm{pH}$ difference between the control and fortified beverage samples.

Effect of Microcapsule Fortification in DAS$C P E B$ Viscosity. At the time of the microcapsule incorporation, DASCPEB exhibited an apparent viscosity reduction in the control, as a result of mixing operation and microcapsule interaction. The values of apparent viscosity of the supplemented DASCPEB and control samples gradually decreased during the assessed period (Figure 6; Table 2), being more severe in the S-B and S-C samples (3 and $4.5 \mathrm{~g} / 100 \mathrm{~g}$, respectively). As is well known, the storage time influenced the syneresis and the structural rearrangement in the beverage. Several studies confirmed that the microcapsules led to the formation of a weak gel and, as a result, a decrease in viscosity (Comunian et al., 2017; Ghorbanzade et al., 2017; Tan et al., 2018).

Nonetheless, the sample S-A (1.5 g/100 g) did not show a significant difference in the control and had a higher value of apparent viscosity $(0.43 \pm 0.17 \mathrm{~Pa} \cdot \mathrm{s})$ at $21 \mathrm{~d}$. These values are lower than those reported by Comunian et al. (2017) for beverages containing encapsulated echium oil, phytosterol, and sinapic acid at $21 \mathrm{~d}(0.758 \pm 0.08 \mathrm{~Pa} \cdot \mathrm{s})$. Several studies reported an increase or very close viscosity values compared with the control after microcapsule fortification in the beverage, though, using other wall materials and microencapsulation techniques (Goyal et al., 2016; Comunian et al., 2017; Ghorbanzade et al., 2017; Tan et al., 2018). Therefore, it is necessary to carry out more studies to increase viscosity in fortified DASCPEB.

A High Fortification Content Affected the Aggregate Stability. To understand the effect of viscosity on the aggregate size (average particle size), this variable was assessed in storage. The control sample showed a gently increasing size from d 1 to 8; after that time, no changes were revealed (Table 2). An adverse effect was shown in the particle size as a result of fortification. The S-A and S-B particle size increased at the 8th day, and after that, it decreased. The particle size of S-C sample was reduced during the storage time. The rearrangement mentioned in the previous section is evidenced by aggregate size, being more severe in $\mathrm{S}-\mathrm{C}$. The beverage is a gel involving protein aggregates (caseins) that capture water within them. This structure is affected by the amount of protein, fat, or other components and their thermodynamic compatibility (Comunian et al., 2017; Tan et al., 2018). Arabic gum is known to generate an anionic effect and a steric repulsion in the surface drop in emulsions (Chanamai and McClements, 2002). This feature makes the microcapsule wall material to generate a steric repulsion, and therefore, it can interact with the cross-linking proteins, generating a disaggregation.

A Small Number of Microcapsules Incorporated Did Not Show a Significant Difference in the DASCPEB Microstructure. The different treatments and control samples did not show significant differences on d 1 (Figure 7), other than some network voids occupied by the microcapsules (Figure $7 \mathrm{G}$ and 
7I). On d 21, the control and S-A samples exhibited a normal network with regular void (Figure 7D and 7F), so it is evident that the gel microstructure was not affected by the $1.5 \mathrm{~g} / 100 \mathrm{~g}$ microcapsule incorporation. By contrast, significant changes occurred with S-B and $\mathrm{S}-\mathrm{C}$ samples, which displayed a strange change in the network (Figure $7 \mathrm{H}$ and $7 \mathrm{~J}$ ), which collapsed, and cracked surfaces replaced it. These observations can be explained by thermodynamic incompatibility between the polysaccharides existing in the wall microcapsule and the caseins (Sah et al., 2016). Nonetheless, it was necessary to assess these interactions and their thermodynamic behavior through MD simulations.

\section{K-Casein and Molecular Interaction}

The predicted $\kappa$-casein structure by I-Tasser had a $\mathrm{C}$-score of -4.13 . This value must be between -5.2 and 2 for a good structure prediction (Zhang, 2008). The MD simulations showed that the $\kappa$-casein solvated in water had an average bond energy of $928.5 \mathrm{kcal} / \mathrm{mol}$ and the $\kappa$-casein-glutathione was $910.1 \mathrm{kcal} / \mathrm{mol}$. This loss in bond energy was due to the $\kappa$-casein-glutathione interaction (Supplemental Video S1, https://doi.org/10 .3168/jds.2019-16729). The glutamate from glutathione formed an ionic bond with the amino group from 139 $\kappa$-casein glutamate and the glycine from glutathione formed a hydrogen bond with the $87 \kappa$-casein alanine (Supplemental Figure S5, https://doi.org/10.3168/jds .2019-16729). The interaction was maintained until the end of the simulation and here we can conclude that SCPE-microcapsule components can interact with milk proteins and help to form a structure in DASCPEB microstructure.

On the other hand, the $\kappa$-casein solvated with glutathione, Arabic gum, maltodextrin, and OA exhibited a bond energy average of $1,157.9 \mathrm{kcal} / \mathrm{mol}$. This energy increase was due first to a molecule increase in the simulation box, and second because there is a formation of 2 clusters: one formed by the Arabic gum interacting with $\kappa$-casein and the other one by the interaction of glutathione, Arabic gum, maltodextrin, and OA until the simulation end (Supplemental Video S2, https:// doi.org/10.3168/jds.2019-16729). The structure formed by the interaction of SCPE-microcapsule-milk proteins was affected for a greater affinity toward Arabic gum. This fact could explain the observations shown in experimental assays, referring to microstructure affectation due to microcapsule incorporation.

As mentioned above, C. utilis has endogenous metabolites and cell-wall components, which might contribute to the improvement of host health allowing their ap-

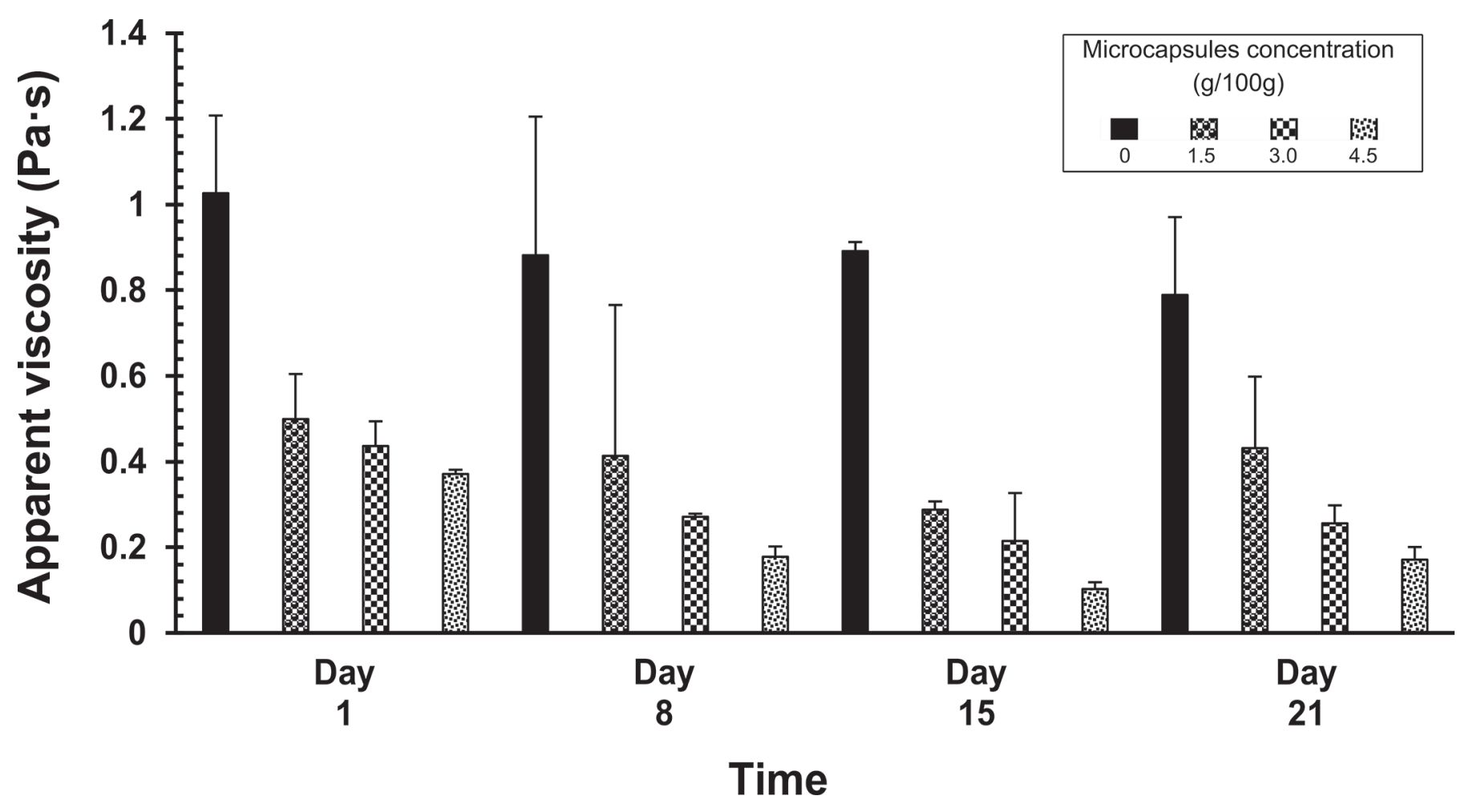

Figure 6. Apparent viscosity for supplemented dairy single-cell protein extract beverages (DASCPEB) in storage. The graphic shows how the microcapsules and time affect DASCPEB apparent viscosity. Error bars represent SD. 

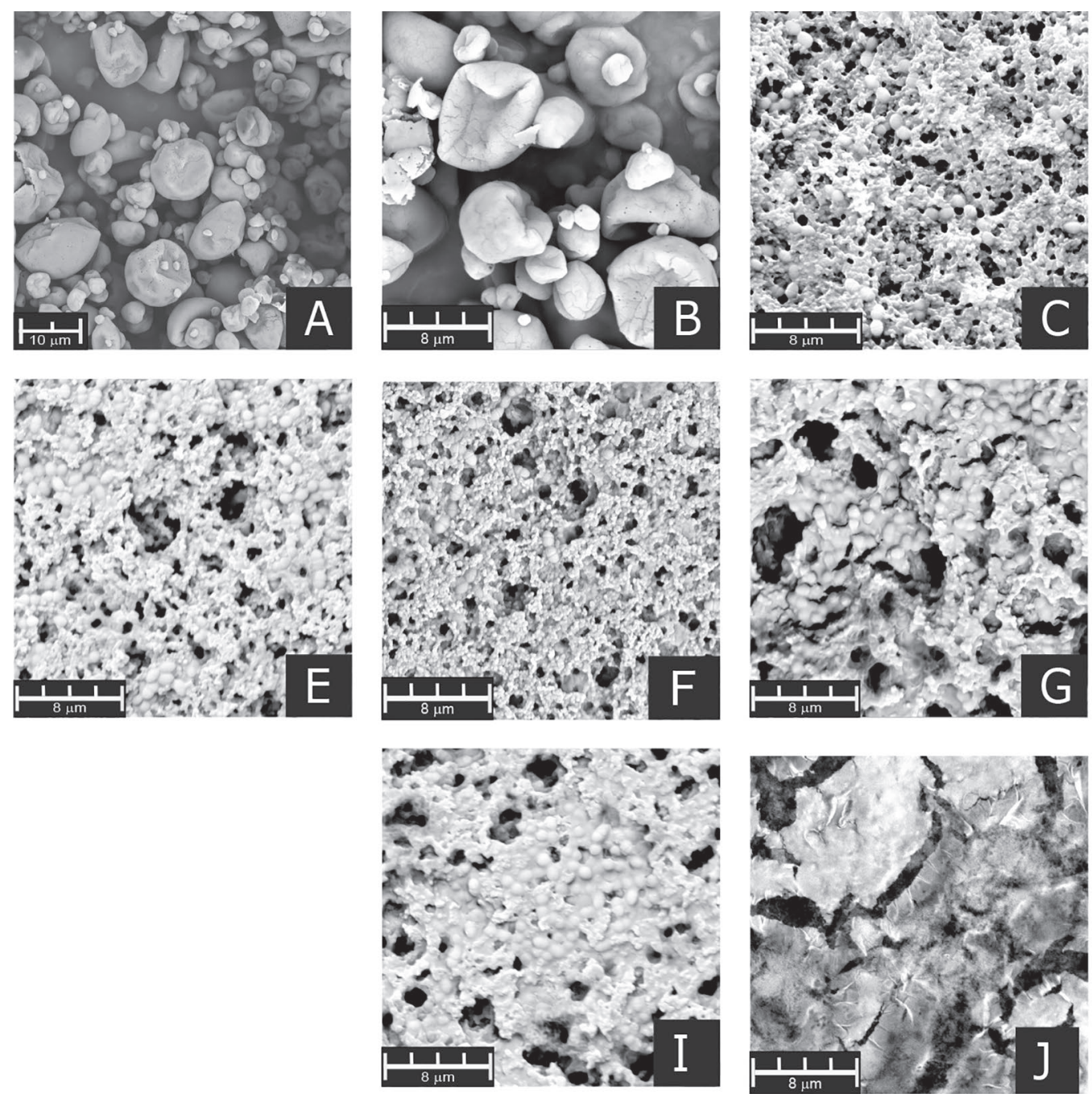
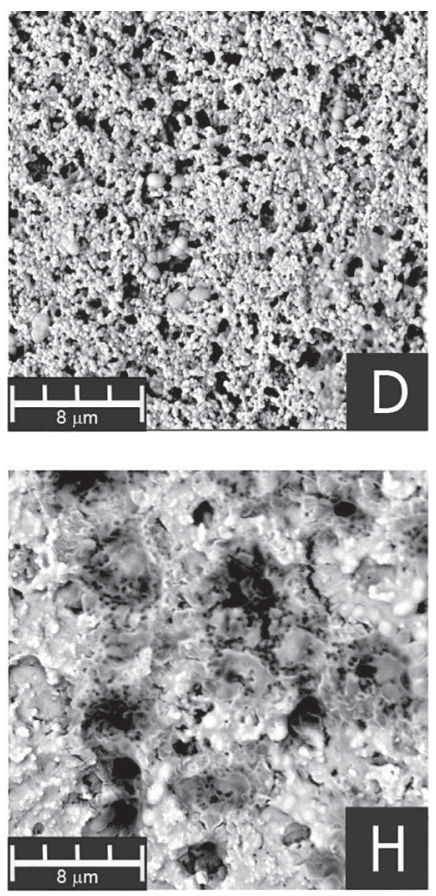

$\mathrm{H}$

Figure 7. Microcapsule micrographics and supplemented dairy single-cell protein extract beverages (DASCPEB). (A) Microcapsules at $5,000 \times$, (B) microcapsules at 1,000×, (C) C30 (control) on d 1, (D) C30 (control) on d 21, (E) S-A on d 1, (F) S-A on d 21, (G) S-B on d 1, (H) S-B on d 21, (I) S-C on d 1, and (J) S-C on d 21. Images A and B show the typical microcapsule morphology. Images C to J display the different treatments and how microcapsules and time affect DASCPEB microstructure.

plication in a large range of functional foods (Buerth et al., 2011a; Tomita et al., 2012). These bioactive compounds, known as postbiotics, have been recently shown to present a wide range of biological activities including antioxidant, anti-hypertensive, immunomodulatory, and anti-inflammatory activities (Tsilingiri and Rescigno, 2013; Aguilar-Toalá et al., 2018; Malashree et al., 2019). The mechanism of postbiotics bioactivities associated with the metabolites and cell-wall components released by $C$. utilis still have to be elucidated through in vitro and in vivo studies.

The MD simulations showed a possible interaction between one component from $C$. utilis extracts, as is the glutathione, and one protein from the milk, as is the $\kappa$-casein. However, this interaction was affected by the microcapsule wall materials incorporated, such as the Arabic gum, which has a greater affinity with $\kappa$-casein. The MD simulations can help us understand the interaction of the molecules in a product formulation, turning into a very useful tool for rational design.

Table 1. Feed emulsion and microcapsule characterization $( \pm \mathrm{SD})$

\begin{tabular}{lc}
\hline Sample & $\begin{array}{c}\text { Sample dried in } \\
\text { pilot spray dryer }\end{array}$ \\
\hline Drop size emulsion D[4,3] $(\mu \mathrm{m})$ & $1.58 \pm 0.06$ \\
Total suspended solids & $23.3 \pm 0.3$ \\
Microcapsule size D[4,3] $(\mu \mathrm{m})$ & $5.18 \pm 0.62$ \\
Total oleic acid (g/g of microcapsules) & 0.150 \\
Total free oleic acid (g/g of microcapsules) & 0.074 \\
Microencapsulation efficiency $(\%)$ & $50.80 \pm 0.35$ \\
\hline
\end{tabular}


Table 2. Effect of microencapsulated oleic acid in fortified dairy single-cell protein extract beverages $( \pm \mathrm{SD})$

\begin{tabular}{|c|c|c|c|c|}
\hline \multirow[b]{2}{*}{ Beverage type } & \multicolumn{4}{|c|}{ Storage period (d) } \\
\hline & 1 & 8 & 15 & 21 \\
\hline \multicolumn{5}{|l|}{$\mathrm{pH}$} \\
\hline C30 $(\text { control })^{1}$ & $4.25 \pm 0.030$ & $4.10 \pm 0.005$ & $4.03 \pm 0.004$ & $4.01 \pm 0.004$ \\
\hline $\mathrm{S}-\mathrm{A}^{2}$ & $4.26 \pm 0.004$ & $4.10 \pm 0.013$ & $4.08 \pm 0.012$ & $4.06 \pm 0.008$ \\
\hline $\mathrm{S}-\mathrm{B}^{2}$ & $4.27 \pm 0.006$ & $4.16 \pm 0.000$ & $4.17 \pm 0.005$ & $4.13 \pm 0.003$ \\
\hline $\mathrm{S}-\mathrm{C}^{2}$ & $4.31 \pm 0.013$ & $4.20 \pm 0.010$ & $4.19 \pm 0.005$ & $4.13 \pm 0.023$ \\
\hline \multicolumn{5}{|c|}{ Apparent viscosity $(\mathrm{Pa} \cdot \mathrm{s})$} \\
\hline C30 (control) & $1.027 \pm 0.181$ & $0.882 \pm 0.324$ & $0.892 \pm 0.021$ & $0.789 \pm 0.182$ \\
\hline S-A & $0.499 \pm 0.105$ & $0.413 \pm 0.352$ & $0.288 \pm 0.019$ & $0.431 \pm 0.167$ \\
\hline $\mathrm{S}-\mathrm{B}$ & $0.436 \pm 0.058$ & $0.271 \pm 0.007$ & $0.215 \pm 0.112$ & $0.256 \pm 0.042$ \\
\hline $\mathrm{S}-\mathrm{C}$ & $0.371 \pm 0.010$ & $0.178 \pm 0.024$ & $0.102 \pm 0.016$ & $0.171 \pm 0.03$ \\
\hline \multicolumn{5}{|c|}{ Particle size $\mathrm{D}[4,3](\mu \mathrm{m})$} \\
\hline C30 (control) $)^{2}$ & $9.91 \pm 0.269$ & $10.60 \pm 0.283$ & $10.65 \pm 0.636$ & $10.50 \pm 0.00$ \\
\hline S-A & $8.61 \pm 0.502$ & $9.57 \pm 0.587$ & $8.25 \pm 0.304$ & $7.98 \pm 0.11$ \\
\hline S-B & $7.68 \pm 0.820$ & $8.48 \pm 0.106$ & $7.29 \pm 0.311$ & $7.12 \pm 0.22$ \\
\hline $\mathrm{S}-\mathrm{C}$ & $7.10 \pm 0.007$ & $7.09 \pm 0.014$ & $6.51 \pm 0.035$ & $6.37 \pm 0.18$ \\
\hline
\end{tabular}

${ }^{1} \mathrm{pH}$ of the control sample before the storage was $4.48 \pm 0.026$.

${ }^{2} \mathrm{pH}$ of the samples before supplementation and storage was $4.47 \pm 0.026$.

\section{CONCLUSIONS}

Candida utilis extracts were successfully used as a substitute for a milk fraction in fermented milk beverages. A $30 \% \mathrm{vol} / \mathrm{vol}$ of substitution was possible without substantial changes in the microstructure of the beverage, but with a viscosity reduction of $0.66 \pm 0.077$ Pa.s compared with the control sample. Furthermore, the fermented beverage was successfully fortified with $1.5 \mathrm{~g} / 100 \mathrm{~g}$ of microcapsules that contain OA, without showing significant changes in the microstructure. However, microcapsule fortification affected viscosity, as well as the storage conditions. The difference is that even though both decreased viscosity, the decreasing behavior observed under storage conditions was normal compared with the control sample. Therefore, it is appropriate to fortify the beverage using microcapsules containing different wall material. The present work aimed to design a beverage model applying multiscale design. This model works as a platform to further engineering dairy beverages in response to the customer's needs and preferences. Additional engineering will be required to improve our model regarding its sensory and organoleptic properties (e.g., color, aroma, taste, and bioactivity), which might influence customer acceptance.

\section{ACKNOWLEDGMENTS}

We thank the Universidad de Los Andes for financial support and the researchers at Grupo de Diseño de Productos y Procesos for their constant contributions, correct observations, and great knowledge. The authors declare no conflicts of interest. This research was conducted in the absence of any commercial or financial relationships that could be construed as a potential conflict of interest. All authors approved the final article.

\section{REFERENCES}

Abedi, A. S., M. Rismanchi, M. Shahdoostkhany, A. Mohammadi, and H. Hosseini. 2016. Microencapsulation of Nigella sativa seeds oil containing thymoquinone by spray-drying for functional yogurt production. Int. J. Food Sci. Technol. 51:2280-2289. https://doi .org/10.1111/ijfs.13208.

Aguilar-Raymundo, V. G., and J. F. Vélez-Ruiz. 2019. Yoghurt-type beverage with partial substitution of milk by a chickpea extract: Effect on physicochemical and flow properties. Int. J. Dairy Technol. 72:266-274. https://doi.org/10.1111/1471-0307.12581.

Aguilar-Toalá, J. E., R. García-Varela, H. Garcia, V. Mata-Haro, A. F. González-Córdova, B. Vallejo-Cordoba, and A. Hernandez-Mendoza. 2018. Postbiotics: An evolving term within the functional foods field. Trends Food Sci. Technol. 75:105-114.

Alconchel-Gago, F., A. Santamaría, and I. Túnez. 2014. Antioxidant effect of oleic acid and hydroxytyrosol in an experimental model similar to Huntington's disease. Actual. Medica 99:60-64. https:// doi.org/10.15568/am.2014.792.or01.

AOAC International. 1995. Official Method 934.01. Moisture in Animal Feed. AOAC International, Rockville, MD.

Bakry, A. M., S. Abbas, B. Ali, H. Majeed, M. Y. Abouelwafa, A. Mousa, and L. Liang. 2016. Microencapsulation of oils: A comprehensive review of benefits, techniques, and applications. Comprehensive Reviews Food Sci. Food Safety 15:143-182. https://doi .org/10.1111/1541-4337.12179.

Barkallah, M., M. Dammak, I. Louati, F. Hentati, B. Hadrich, T. Mechichi, M. A. Ayadi, I. Fendri, H. Attia, and S. Abdelkafi. 2017. Effect of Spirulina platensis fortification on physicochemical, textural, antioxidant and sensory properties of yogurt during fermentation and storage. Lebensm. Wiss. Technol. 84:323-330. https:// doi.org/10.1016/j.lwt.2017.05.071.

Bremner, J. M. 1996. Nitrogen-Total. Pages 1085-1121 in Methods of Soil Analysis. Part 3-Chemical Methods. D. L. Sparks, A. L. Page, P. A. Helmke, R. H. Loeppert, P. N. Soltanpour, M. A. Tabatabai, C. T. Johnston, and M. E. Sumner, ed. Soil Science Society of America Inc., Madison, WI. 
Buerth, C., C. J. Heilmann, F. M. Klis, C. G. de Koster, J. F. Ernst, and D. Tielker. 2011a. Growth-dependent secretome of Candida utilis. Microbiology 157:2493-2503. https://doi.org/10.1099/mic.0 .049320-0.

Buerth, C., C. J. Heilmann, F. M. Klis, C. G. de Koster, J. F. Ernst, and D. Tielker. 2011b. Growth-dependent secretome of Candida utilis. Microbiology 157:2493-2503. https://doi.org/10.1099/mic.0 .049320-0.

Buerth, C., D. Tielker, and J. F. Ernst. 2016. Candida utilis and Cyberlindnera (Pichia) jadinii: Yeast relatives with expanding applications. Appl. Microbiol. Biotechnol. 100:6981-6990. https://doi .org/10.1007/s00253-016-7700-8.

Carrillo, L. M., M. A. Zarate, E. J. Wong Paz, and D. B. Muñiz. 2010. Producción de biomasa de Candida utilis (Henneberg) a partir de melaza. U Tecnociencia 4:32-40.

Castro, W. F., A. G. Cruz, M. S. Bisinotto, L. M. R. Guerreiro, J. A. F. Faria, H. M. A. Bolini, and R. Deliza. 2013. Development of probiotic dairy beverages: Rheological properties and application of mathematical models in sensory evaluation. J. Dairy Sci. 96:16-25. https://doi.org/10.3168/jds.2012-5590.

Chanamai, R., and D. J. McClements. 2002. Comparison of gum Arabic, modified starch, and whey protein isolate as emulsifiers: Influence of $\mathrm{pH}, \mathrm{CaCl}_{2}$ and temperature. J. Food Sci. 67:120-125. https: //doi.org/10.1111/j.1365-2621.2002.tb11370.x.

Charpentier, J. 2002. The triplet "molecular processes - product process" engineering: The future of chemical engineering? Chem. Eng. Sci. 57:4667-4690.

Chouchouli, V., N. Kalogeropoulos, S. J. Konteles, E. Karvela, D. P. Makris, and V. T. Karathanos. 2013. Fortification of yoghurts with grape (Vitis vinifera) seed extracts. Lebensm. Wiss. Technol. 53:522-529. https://doi.org/10.1016/j.lwt.2013.03.008.

Comunian, T. A., I. E. Chaves, M. Thomazini, I. C. F. Moraes, R. Ferro-Furtado, I. A. de Castro, and C. S. Favaro-Trindade. 2017. Development of functional yogurt containing free and encapsulated echium oil, phytosterol and sinapic acid. Food Chem. 237:948-956. https://doi.org/10.1016/j.foodchem.2017.06.071.

Cordeiro, M. A., E. L. S. Souza, R. M. E. Arantes, C. F. Balthazar, J. T. Guimarães, H. Scudino, H. L. A. Silva, R. S. Rocha, M. Q. Freitas, E. A. Esmerino, M. C. Silva, T. C. Pimentel, D. Granato, R. G. B. Costa, A. G. Cruz, and F. S. Martins. 2019. Fermented whey dairy beverage offers protection against Salmonella enterica ssp. enterica serovar Typhimurium infection in mice. J. Dairy Sci. https://doi.org/10.3168/jds.2019-16340.

Dalgleish, D. G., and M. Corredig. 2012. The structure of the casein micelle of milk and its changes during processing. Annu. Rev. Food Sci. Technol. 3:449-467. https://doi.org/10.1146/annurev-food -022811-101214.

Di Battista, C. A., D. Constenla, M. V. Ramírez-Rigo, and J. Piña. 2015. The use of Arabic gum, maltodextrin and surfactants in the microencapsulation of phytosterols by spray drying. Powder Technol. 286:193-201. https://doi.org/10.1016/j.powtec.2015.08.016.

Estrada, J. D., C. Boeneke, P. Bechtel, and S. Sathivel. 2011. Developing a strawberry yogurt fortified with marine fish oil. J. Dairy Sci. 94:5760-5769. https://doi.org/10.3168/jds.2011-4226.

FAO and FINUT. 2012. Grasas y Ácidos Grasos En Nutrición Humana Consulta de Expertos. 2nd ed. FINUT, ed. Organización de las Naciones Unidad para la Alimentación y la agridultura (FAO), Fundación Iberoamericana de Nutrición (FINUT), Ginebra.

Feng, Z. Z., M. Y. Li, Y. T. Wang, and M. J. Zhu. 2018. Astaxanthin from Phaffia rhodozyma: Microencapsulation with carboxymethyl cellulose sodium and microcrystalline cellulose and effects of microencapsulated astaxanthin on yogurt properties. LWT 96:152160. https://doi.org/10.1016/j.lwt.2018.04.084.

García, R., Y. Izquierdo, M. Ribas, K. Tortoló, M. L. Ibáñez, O. León, M. Saura, and G. Saura. 2014. Effects of urea supplementation on Candida utilis biomass production from distillery waste. Waste Biomass Valoriz. 5:119-124. https://doi.org/10.1007/s12649-013 -9209-z.

Ghorbanzade, T., S. M. Jafari, S. Akhavan, and R. Hadavi. 2017. Nano-encapsulation of fish oil in nano-liposomes and its applica- tion in fortification of yogurt. Food Chem. 216:146-152. https:// doi.org/10.1016/j.foodchem.2016.08.022.

Gonçalves-de-Albuquerque, C. F., I. M. Medeiros-de-Moraes, F. M. J. De Oliveira, P. Burth, P. T. Bozza, M. V. C. Faria, A. R. Silva, and H. C. De Castro-Faria-Neto. 2016. Omega-9 oleic acid induces fatty acid oxidation and decreases organ dysfunction and mortality in experimental sepsis. PLoS One 11:e0153607. https://doi.org/10 .1371/journal.pone.0153607.

Goyal, A., V. Sharma, M. K. Sihag, A. K. Singh, S. Arora, and L. Sabikhi. 2016. Fortification of dahi (Indian yoghurt) with omega-3 fatty acids using microencapsulated flaxseed oil microcapsules. J. Food Sci. Technol. 53:2422-2433. https://doi.org/10.1007/s13197 $-016-2220-1$.

Ikram, S., and S. Ahnmed. 2016. Natural Polymers: Derivatives, Blends And Composites [e-Book]. Volume I. Nova Science Publishers Inc., New York, NY.

Jiménez-Martín, E., A. Gharsallaoui, and T. A. Rojas. 2014. Suitability of using monolayered and multilayered emulsions for microencapsulation of $\omega-3$ fatty acids by spray drying: Effect of storage at different temperatures. Food Bioprocess. Technol. 8:100. https: //doi.org/10.1007/s11947-014-1382-y.

Kim, S., P. A. Thiessen, E. E. Bolton, J. Chen, G. Fu, A. Gindulyte, L. Han, J. He, S. He, B. A. Shoemaker, J. Wang, B. Yu, J. Zhang, and S. H. Bryant. 2016. PubChem Substance and Compound databases. Nucleic Acids Res. 44:D1202-D1213. https://doi.org/10 .1093/nar/gkv951.

Lee, W. J., and J. A. Lucey. 2004. Structure and physical properties of yogurt gels: Effect of inoculation rate and incubation temperature. J. Dairy Sci. 87:3153-3164. https://doi.org/10.3168/jds.S0022 $-0302(04) 73450-5$

Lee, W. J., and J. A. Lucey. 2010. Formation and physical properties of yogurt. Asian-australas. J. Anim. Sci. 23:1127-1136. https://doi .org/10.5713/ajas.2010.r.05

López Hernández, O. D. 2010. Microencapsulación de sustancias oleosas mediante secado por aspersión. Rev. Cuba. Farm. 44:381-389.

Lucca, M. E., M. E. Romero, and D. A. S. Callieri. 1995. Continuous culture of Candida utilis: Influence of medium nitrogen concentration. World J. Microbiol. Biotechnol. 11:515-518. https://doi.org/ $10.1007 /$ BF00286365.

Macedo, R. C., and J. F. Vélez-Ruíz. 2015. Propiedades fisicoquímicas y de flujo de un yogur asentado enriquecido con microcápsulas que contienen ácidos grasos omega 3. Inf. Tecnol. 26:87-96. https://doi .org/10.4067/S0718-07642015000500012.

Malashree, L., V. Angadi, S. Yadav, and R. Prabha. 2019. "Postbiotics"-One step ahead of probiotics. Int. J. Current Microbiol. Appl. Sci. 8:2049-2053.

Øverland, M., A. Karlsson, L. T. Mydland, O. H. Romarheim, and A. Skrede. 2013. Evaluation of Candida utilis, Kluyveromyces marxianus and Saccharomyces cerevisiae yeasts as protein sources in diets for Atlantic salmon (Salmo salar). Aquaculture 402-403:1-7. https://doi.org/10.1016/j.aquaculture.2013.03.016.

Öztürk, H. İ., S. Aydın, D. Sözeri, T. Demirci, D. Sert, and N. Akın. 2018. Fortification of set-type yoghurts with Elaeagnus angustifolia L. flours: Effects on physicochemical, textural, and microstructural characteristics. Lebensm. Wiss. Technol. 90:620-626. https://doi .org/10.1016/j.lwt.2018.01.012.

Pandalaneni, K., J. K. Amamcharla, C. Marella, and L. E. Metzger. 2018. Influence of milk protein concentrates with modified calcium content on enteral dairy beverage formulations: Physicochemical properties. J. Dairy Sci. 101:9714-9724. https://doi.org/10.3168/ jds.2018-14781.

Pelaes, A. C., P. A. Goto, L. N. Hanai, S. M. Gomes-da-Costa, B. A. de Abreu Filho, C. Nakamura, and P. T. Matumoto-Pintro. 2015. Microbiological, functional and rheological properties of low fat yogurt supplemented with Pleurotus ostreatus aqueous extract. Lebensm. Wiss. Technol. 64:1028-1035. https://doi.org/10.1016/j .lwt.2015.07.003.

Plimpton, S. 1995. Fast parallel algorithms for short-range molecular dynamics. J. Comput. Phys. 117:1-19. https://doi.org/10.1006/ jcph.1995.1039. 
Pradilla, D., W. Vargas, and O. Alvarez. 2015. The application of a multi-scale approach to the manufacture of concentrated and highly concentrated emulsions. Chem. Eng. Res. Des. 95:162-172. https://doi.org/10.1016/j.cherd.2014.10.016.

Prakash, M., and M. H. Mohamed. 2017. SCP production from Candida utilis isolated from Vellar estuary. Int. J. Adv. Res. Biol. Sci. 4:34-43. https://doi.org/10.22192/ijarbs.2017.04.01.004.

Puvanenthiran, A., C. Stevovitch-Rykner, T. H. McCann, and L. Day. 2014. Synergistic effect of milk solids and carrot cell wall particles on the rheology and texture of yoghurt gels. Food Res. Int. 62:701708. https://doi.org/10.1016/j.foodres.2014.04.023.

Rodríguez, B., L. M. Mora, D. Oliveira, A. C. Euler, L. Larav, and P. Lezcano. 2011. Chemical composition and nutritive value of torula yeast (Candida utilis), grown on distiller's vinasse, for poultry feeding. Cuban J. Agric. Sci. 45:261-265.

Rodriguez, R., S. Vargas, M. Estevez, F. Quintanilla, A. Trejo-Lopez, and A. R. Hernández-Martínez. 2013. Use of Raman spectroscopy to determine the kinetics of chemical transformation in yogurt production. Vib. Spectrosc. 68:133-140. https://doi.org/10.1016/j .vibspec.2013.06.004

Rodríguez, R., S. Vargas, F. Quintanilla, A. Trejo, C. Regalado, B. García, and M. González-Torres. 2015. Transformation kinetics during fermented milk production using Lactobacillus johnsoni (La1) and Streptococcus thermophilus: A comparison with yogurt inoculum. Food Biophys. 10:375-384. https://doi.org/10.1007/ s11483-015-9406-3.

Roy, A., A. Kucukural, and Y. Zhang. 2010. I-TASSER: A unified platform for automated protein structure and function prediction. Nat. Protoc. 5:725-738. https://doi.org/10.1038/nprot.2010.5.

Sah, B. N. P., T. Vasiljevic, S. McKechnie, and O. N. Donkor. 2016. Physicochemical, textural and rheological properties of probiotic yogurt fortified with fibre-rich pineapple peel powder during refrigerated storage. Lebensm. Wiss. Technol. 65:978-986. https:// doi.org/10.1016/j.lwt.2015.09.027.

Sakin-Yilmazer, M., B. Koç, P. Balkir, and F. Kaymak-Ertekin. 2014. Rheological behavior of reconstituted yoghurt powder-An optimization study. Powder Technol. 266:433-439. https://doi.org/10 .1016/j.powtec.2014.06.060.

Shirts, M. R., C. Klein, J. M. Swails, J. Yin, M. K. Gilson, D. L. Mobley, D. A. Case, and E. D. Zhong. 2017. Lessons learned from comparing molecular dynamics engines on the SAMPL5 dataset. J. Comput. Aided Mol. Des. 31:147-161. https://doi.org/10.1007/ s10822-016-9977-1.

Stukowski, A. 2010. Visualization and analysis of atomistic simulation data with OVITO-The Open Visualization Tool. Model. Simul. Mater. Sci. Eng. 18:015012. https://doi.org/10.1088/0965-0393/ $18 / 1 / 015012$.

Tan, P. Y., T. B. Tan, H. W. Chang, B. T. Tey, E. S. Chan, O. M. Lai, B. S. Baharin, I. A. Nehdi, and C. P. Tan. 2018. Effects of storage and yogurt matrix on the stability of tocotrienols encapsulated in chitosan-alginate microcapsules. Food Chem. 241:79-85. https:// doi.org/10.1016/j.foodchem.2017.08.075.

Tobajas, M., E. García-Calvo, X. Wu, and J. C. Merchuk. 2003. A simple mathematical model of the process of Candida utilis growth in a bioreactor. World J. Microbiol. Biotechnol. 19:391-398.

Tomita, Y., K. Ikeo, H. Tamakawa, T. Gojobori, and S. Ikushima 2012. Genome and transcriptome analysis of the food-yeast Candida utilis. PLoS One 7:e37226. https://doi.org/10.1371/journal .pone.0037226.

Toniazzo, T., I. F. Berbel, S. Cho, C. S. Fávaro-Trindade, I. C. F Moraes, and S. C. Pinho. 2014. $\beta$-carotene-loaded liposome dispersions stabilized with xanthan and guar gums: Physico-chemical stability and feasibility of application in yogurt. Lebensm. Wiss. Technol. 59:1265-1273. https://doi.org/10.1016/j.lwt.2014.05.021.

Tsilingiri, K., and M. Rescigno. 2013. Postbiotics: What else? Benef. Microbes 4:101-107. https://doi.org/10.3920/BM2012.0046.

Vardjan, T., P. Mohar Lorbeg, and A. Canžek Majhenič. 2018. Stability of prevailing lactobacilli and yeasts in kefir grains and kefir beverages during ten weeks of propagation. Int. J. Dairy Technol. 71:51-60. https://doi.org/10.1111/1471-0307.12463.

Yang, J., R. Yan, A. Roy, D. Xu, J. Poisson, and Y. Zhang. 2015. The I-TASSER suite: Protein structure and function prediction. Nat. Methods 12:7-8. https://doi.org/10.1038/nmeth.3213.

Zhang, Y. 2008. I-TASSER server for protein 3D structure prediction. BMC Bioinformatics 9:40. https://doi.org/10.1186/1471-2105-9 -40 .

Zoete, V., M. A. Cuendet, A. Grosdidier, and O. Michielin. 2011. SwissParam: A fast force field generation tool for small organic molecules. J. Comput. Chem. 32:2359-2368. https://doi.org/10 $.1002 /$ jcc. 21816 . 